\title{
DIRECT MEASUREMENT OF BASAL WATER PRESSURES: PROGRESS AND PROBLEMS
}

\author{
By Steven M. Hodge
}

(Water Resources Division, U.S. Geological Survey, Tacoma, Washington 98402, U.S.A.)

Abstract. In 1975 and 1977, 24 bore holes were drilled to the bed of South Cascade Glacier, Washington, U.S.A., using both electrothermal and hot-water drills. Only two holes connected directly with the basal water system, a significant decrease from the four to five such connections in 13 holes drilled in 1973 and 1974 (Hodge, 1976). Most of the bed, possibly as much as $90 \%$, appears to be hydraulically inactive and isolated from a few active subglacial conduits. Bore holes which penetrate these inactive areas initially should connect eventually with the active basal water system due to bed pressurization by the water standing in the bore hole, provided there is a sufficient supply of water available to form and maintain the connection passageway. These sealed-off areas probably consist of the sub-sole drift and permeability barriers found recently at the bed of Blue Glacier by Engelhardt and others (1978); an increase in the area of bed covered by these features probably caused the decrease in chance of bore-hole connection. This apparently was not due to any external cause but rather was the result of a real internal change in the subglacial hydraulic system which occurred between 1974 and 1975 .

If most of the area of a glacier bed is hydraulically isolated sub-sole drift, or something similar, such features may well control large-scale glacięr sliding changes, since changes in the amount of water having access to the glacier bed will take considerable time to affect the interstitial water pressure in the more widespread sub-sole drift.

Water pressures in the active part of the basal water system of South Cascade Glacier are generally in the range of $50-75 \%$ of the ice overburden pressure. Water levels in a connected bore hole are probably representative over an area of the bed $100 \mathrm{~m}$ or more in extent. A correlation of bore-hole water levels with changes in surface motion supports the idea that the sliding of a temperate glacier is controlled largely by the basal water pressure.

RÉsumÉ. Mesures directes des pressions hydrauliques au fond: progrès et problèmes. En 1975 et 1977,24 forages furent exécutés jusqu'au fond du lit du South Cascade Glacier, Washington, en utilisant simultanément les sondes électriques et à eau chaude. Seulement deux forages se trouvèrent en communication directe avec le réseau hydraulique du fond du glacier; c'est une diminution significative en comparaison des 4 à 5 telles communications qui furent relevées sur les 13 forages réalisés en 1973 et 1974 (Hodge, 1976). La plus grande partie du lit peut-être jusqu'à $90 \%$, apparaît comme hydrauliquement inactive et isolée des chenaux sousglaciaires relativement peu actifs. Les forages qui pénètrent dans ces zones inactives initialement se relieraient éventuellement avec le réseau actif du fond, pourvu qu'il y ait un apport d'eau suffisant dans le forage pour former et maintenir le passage de l'écoulement. Ces zones closes sont probablement formées de sous-sol graveleux et de ces barrières de perméabilité récemment découvertes sous le lit de Blue Glacier par Engelhardt et autres (1978). Une augmentation de la surface du lit occupée par ces zones particulières diminue la probabilité que des connections s'établissent à partir des forages; ceci n'est apparemment pas dû à une cause externe mais était plutôt le résultat d'une modification interne réelle du système hydraulique sous-glaciaire qui serait survenue entre 1974 et 1975 .

Si la plus grande partie de la surface du lit glaciaire est hydrauliquement isolée, par un sous-sol graveleux ou quelque chose de semblable, de tels caractères peuvent constituer une bonne manière de rendre compte des changements à grande échelle du mode de glissement des glaciers, puisque des changements dans la quantité d'eau ayant accès au fond du glacier mettront un temps considérable pour franchir les seuils de perméabilité et affecteront la pression d'eau interstitielle dans le sous-sol graveleux le plus répandu.

Les pressions de l'eau dans la partie active du réseau hydrologique sous-glaciaire du South Cascade Glacier sont généralement de l'ordre de 50 à $75 \%$ de la pression due à la glace sus-jacente. Les niveaux d'eau dans les forages reliés au réseau sont probablement représentatifs d'une surface de lit étendue sur $100 \mathrm{~m}$ ou plus. Une corrélation entre les niveaux de l'eau dans les forages et les changements dans les mouvements en surface fait naître l'idée que le glissement d'un glacier tempéré est dans une large mesure contrôlé par la pression de l'eau au fond.

Zusammenfassung. Direkte Messung des Wasserdrucks am Untergrund: Fortschritte und Probleme. In den Jahren 1975 und 1977 wurden 24 Löcher bis zum Untergrund des South Cascade Glacier, Washington, U.S.A., sowohl mit elektrothermischen wie mit Heisswasser-Bohrern niedergebracht. Nur zwei Bohrlöcher standen in direkter Verbindung zum Wassersystem am Untergrund, - eine beträchtliche Abnahme gegenüber den vier bis fünf Verbindungen dieser Art bei 13 Bohrlöchern in den Jahren 1973 und 1974 (Hodge, 1976). Ein Grossteil des Bettes, möglicherweise bis zu $90 \%$, scheint hydraulisch inaktiv und gegenüber einigen wenigen subglazialen Kanälen isoliert zu sein. Borhlöcher, die anfänglich in diese inaktiven Gebiete eindringen, soilten sich infolge des Druckes, der von dem im Bohrloch stehenden Wasser auf den Untergrund ausgeübt wird, im Laufe der Zeit mit dem aktiven Wassersystem am Untergrund verbinden, vorausgesetzt, dass genügend Wassernachschub vorhanden ist, um den Verbindungskanal zu bilden und aufrecht zu erhalten. Diese versiegelten Gebiete bestehen vermutlich aus der Grundmoräne und undurchlässigen Hindernissen, wie sie jüngst auf den Bett des Blue Glacier von Engelhardt u.a. (1978) gefunden 
wurden; eine Zunahme des mit diesen Erscheinungen bedeckten Untergrundgebietes verursachte wahrscheinlich die Abnahme der Wahrscheinlichkeit für Bohrlochverbindungen. Äussere Ursachen dafür gibt es sichtlich nicht; es liegt vielmehr eine ausschliesslich innere Veränderung im subglazialen hydraulischen System vor, die zwischen 1974 und 1975 eintrat.

Wenn der Grossteil des Gletscherbettes aus hydraulisch isolierter Grundmoräne oder etwas ähnlichem besteht, können solche Erscheinungen sehr wohl das Gleiten des Gletschers stark verändern, da Änderungen in der Menge des Wassers, das Zugang zum Gletscherbett hat, beträchtliche Zeit benötigen, bevor sie den Druck des Zwischenwassers in der weiter ausgedehnten Grundmoräne beeinflussen können.

Der Wasserdruck im aktiven Teil des Wassersystems am Untergrund des South Cascade Glacier liegt im allgemeinen im Bereich von $50-75 \%$ des Druckes des überlagernden Eises. Der Wasserstand in einem verbundenen Bohrloch ist vermutlich für einen Untergrundsbereich von Ioo $\mathrm{m}$ oder mehr Ausdehnung repräsentativ. Die Korrelation zwischen dem Wasserstand in einem Bohrloch und den Änderungen der repräsentativ. Die Korrelation zwischen dem Wasserstand in einem Bohrloch und den Anders weitgehend vom Wasserdruck am Untergrund geregelt wird.

\section{INTRODUGTION}

In 1973 and 1974 it was found that bore-hole drilling techniques could be used to connect with an active water system at or near the bed of South Cascade Glacier, Washington (Hodge, 1976). Observations suggested that this system was indeed the subglacial, or basal, water system considered to exist at the bed of a temperate glacier (Shreve, 1972). Furthermore, the bore holes themselves appeared to have little, if any, effect on the water level, which in a connected bore hole probably is a direct measurement of the average basal water pressure over an area of the bed at least $10 \mathrm{~m}$ in extent.

Of 13 holes drilled in these 2 years (Fig. I), seven connected while drilling: four definitely at the bed, one probably at the bed, and two at intermediate depths. * An eighth bore hole connected naturally $6 \mathrm{~d}$ after drilling was terminated. Based on this relatively high "chance" of connection (about $55-60 \%$ ), more drilling was planned with the hope of obtaining continuous water-level data for at least I year in an array of bore holes over the entire glacier. Related experiments, such as the injection of dye tracers at the bed and the measurement of surface ice motion and bore-hole deformation, were also planned.

\section{DRILLING PROGRAM $1975-77$}

In the early spring and early summer of 1974 , I4 bore holes were drilled in the lower half of the accumulation area (Fig. I). The same electrothermal "hot points" were used, and the drill-rate and water level monitored as in previous years. Drilling was maintained as long as possible in the debris-laden ice near the glacier bed. However, a connection was not obtained until the fourteenth hole (75-14). No more bore holes were attempted that year but two of the earlier holes eventually connected naturally: hole 75-1 6 weeks after drilling and hole $75^{-8}$ 3 weeks after drilling.

The next year, 1976, was devoted to developing and testing a hot-water drill in the hope that, besides being much faster, it would penetrate the debris-laden ice near the bed more easily and thus be more effective in connecting with the basal water system than electrothermal drills. Drill-rates as high as $160 \mathrm{~m} \mathrm{~h}^{-1}$ were achieved and a hole could be drilled to the bed in about $2.5 \mathrm{~h}$ compared to about $50 \mathrm{~h}$ with electrothermal drills.

In early summer of 1977 , ten bore holes were drilled with this new drill. Again, however, only one bore hole (77-I) connected with the basal water system. At the very end of the field season, about 4-6 weeks after drilling, the water level in one or two of the remaining bore holes was starting to drop, so it is possible that more holes eventually formed a connection.

In addition to the drilling, about 425 radio echo-sounding measurements were made in I 975 using the $5 \mathrm{MHz}$ mono-pulse temperate-glacier sounder developed by Watts and others (1975). The resulting bed contours (Fig. I) are generally accurate to about $\pm 5 \mathrm{~m}$ but larger

* Numbers used here for the 1973 and 1974 bore holes are different from those used in the previous paper (Hodge, I 976). The correspondence is: $\mathrm{I}(\mathrm{old})=73^{-\mathrm{I}}($ new), $2=73-2,5=73-5,6=74-\mathrm{I}, 8=74-3,10=74-5$, $\mathrm{II}=74-6$, and $12=74-7$. 


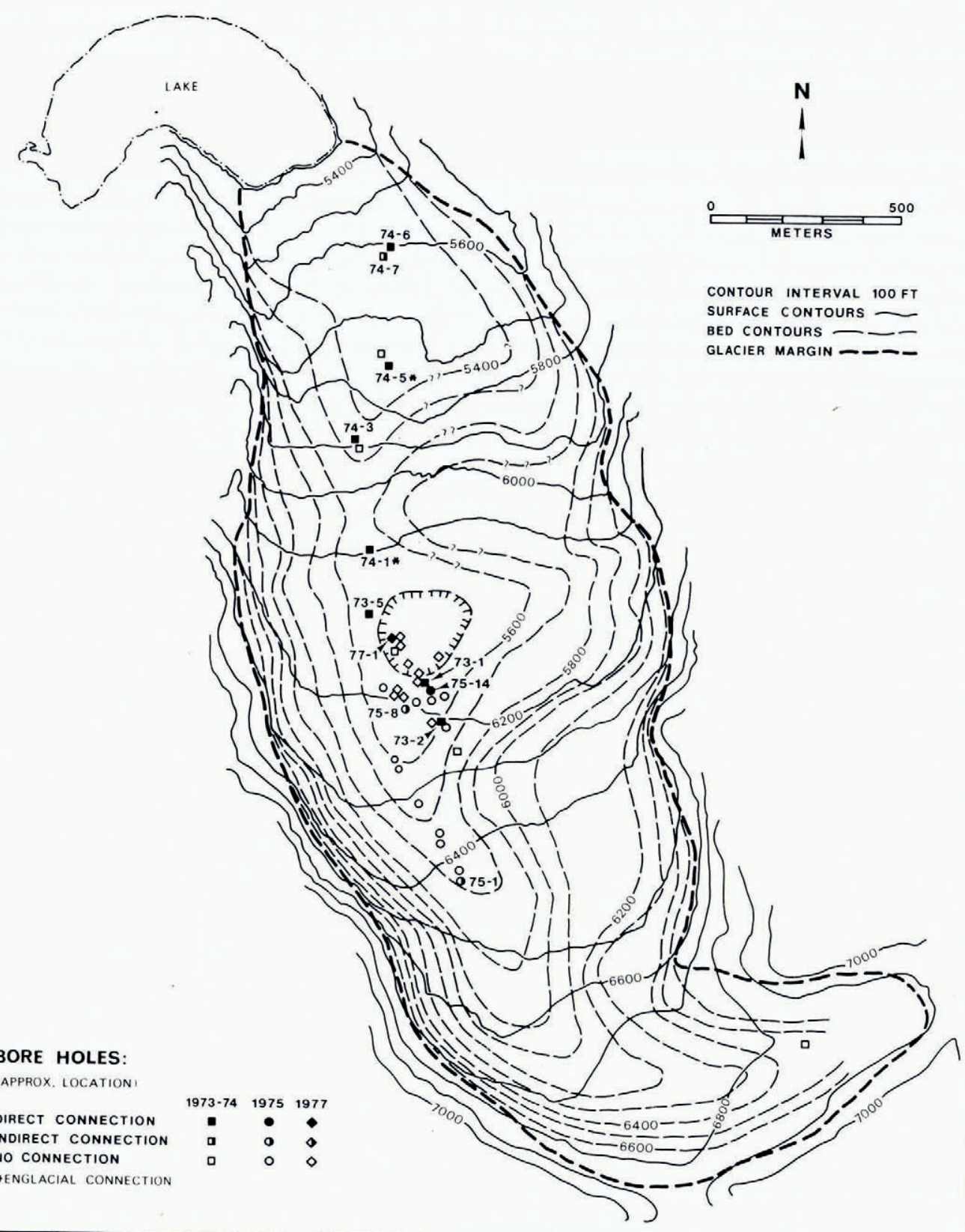

Fig. I. Approximate location of bore holes, South Cascade Glacier, 1973-77. Bore holes which connected with the subglacial water system are labelled with the year and hole number for that year. The locations are superimposed on a new map of the bed topography, obtained from radio echo-sounding in 1975 (see text). 
uncertainty exists where noted with question marks and also over most of the terminus area due to non-existent or ambiguous returns. In addition, the surface contours and glacier margin have changed considerably in the terminus area since the topographic mapping of I 964 . In the central area of the glacier, where most of the 1975 and 1977 bore holes were drilled, there is a large enclosed depression in the bed. Presumably, a lake would probably form here if the ice were removed.

\section{Discussion OF THE DRILLING RESUlTS}

The chance of a subglacial connection occurring while drilling decreased from four (or possibly five) in 13 during $1973-74$ to two in 24 during $1975-77$. Does this represent a real change or simply a probable statistical variation? If we assume the 1975-77 results imply the probability of connection of any given hole is $p=2 / 24=0.083$, then the probability of four connections in 13 attempts can be calculated using the binomial frequency function to be 0.016 , and of five connections, o.003. Conversely, if we assume the 1973-74 results imply the probability of connection is $p=4 / \mathrm{I}_{3}=0.310$, or $p=5 / 13=0.385$, then the probability of two connections in 24 attempts is only 0.008 or $0.00 \mathrm{I}$, respectively.

Thus the chance of this representing just a "normal" statistical variation is very small, and it seems highly likely that some real change did occur, either in the actual subglacial water system or in the techniques used to connect with it.

No change in equipment or technique occurred between 1974 and 1975. Furthermore, connections were as infrequent in 1975 with the electrothermal drill as they were in 1977 with the hot-water drill, a device which, if anything, should have enhanced the ability to make a connection. Nor did the action of the drill at the bed seem to improve the chance of connection; the one hole that was successful with the hot-water drill (77-I) connected within seconds after the drill stopped abruptly at the bed, whereas no connection was made in the remaining nine holes even though hot water was pumped against the interface for over an hour or so.

The location of the drilling does not provide an explanation either. Many of the 1975 bore holes and all of the 1977 bore holes were in the same general area as the 1973 ones, where three of five holes connected. In one case, a hole (75-14) drilled as near as possible to the site of a previous connected hole $\left(73^{-1}\right)$ also connected but, in another case, two holes drilled at the site of another previously connected hole $\left(73^{-2}\right)$ did not connect.

Thus a real change probably occurred in the subglacial water system. One explanation for this could be a general increase in water input. This might eventually enlarge the conduits, lower water pressures, and thereby result in a smaller fraction of the bed covered by an active water system. The water level in the one bore hole which connected in 1977 was, in fact, significantly deeper by about $25-40 \%$ than in the previous years. On the other hand, water levels in the three connected bore holes in 1975 were not significantly different from those of 1973 and 1974. Moreover, total summer ablation did not change significantly from one year to the next. Total ablation in 1977 was, if anything, slightly below average and the observed low water levels were probably due to a few weeks of abnormal, very hot, sunny weather which occurred during and immediately before the observations.

It is thus difficult to attribute the changes to external causes. Instead, the conclusion is that the decrease in the chance of connection was due to a real change in the subglacial hydraulic system. Somehow, a greater area of the glacier bed became isolated from the active part of the subglacial water system. Possibly this was caused by motion of the ice cutting off the flow of water at some point, which, as pointed out by Nye (1973), could happen for channels cut into the ice (rather than into the bedrock).

Whether or not a connection takes place seems to depend primarily on the characteristics of the particular location on the bed interface that the drill happens to intersect. It is either an area already connected to the active basal water system or it is an area sealed off from such a 
system. Such hydraulically inactive areas must be at least several meters in extent, otherwise injecting hot water into them for over an hour would probably force a connection. If the chance of making a subglacial connection while drilling is taken as an index of the relative area of the glacier bed connected to the active basal water system, then the sealed-off areas increased from $60-70 \%$ of the total bed area in $1973-74$ to about $90 \%$ in $1975-77$. These figures should be treated as only very approximate ones since all the bore holes were not randomly or uniformly spaced, many being deliberately drilled close together or at the site of a previous year's hole. Nevertheless, it appears that most of the bed of South Cascade Glacier is hydraulically inactive and isolated from a few active subglacial conduits, and that the relative proportion of active to inactive areas changes significantly with time.

Weertman (1972) showed that a dense network of small channels, either ones incised upward into the ice (termed Röthlisberger, or R, channels by Weertman) or ones incised downward into the bedrock (termed Nye channels), cannot exist under an ordinary glacier. This is compatible with the finding that there are relatively few active subglacial conduits at the bed of South Cascade Glacier. Weertman also concluded that a single large $\mathrm{R}$ channel probably runs down the thalweg over a major portion of its length. The distribution of the South Cascade Glacier bore holes is not adequate enough to test this, but the connected bore holes do lie on or close to the thalweg, so Weertman's analysis is, at least, not contradicted.

In the last two years of drilling, more holes connected after drilling was completed than did during drilling. These "delayed" connections could be due to movement of an active conduit through the ice to the bore hole. However, it is difficult to explain why such migration of the conduits should take place. Alternatively, they could be caused by movement of the bore hole into a stationary conduit, such as a Nye channel incised into the bedrock. The sliding motion of South Cascade Glacier, on the other hand, is probably so small that this mechanism is unlikely to account for all the delayed connections. Instead, it seems more probable that once a sealed-off area is penetrated and thereby "pressurized" by the column of water in the bore hole, sufficient ice-bed separation eventually takes place that a connection can be forced through the seal to the active subglacial water system. Provided the bore hole does not close off by ice deformation or form an englacial "leak", there is no limit to how long this process may take, since surface melt streams or the perched water-table in the firn can easily provide enough water to maintain a head which is typically at least $5 \%$ higher than the ice overburden pressure at the bed. A connection could not be forced through a seal where the overburden pressure was sufficiently enhanced locally by bed roughness, but it is unlikely such enhancement would completely enclose a given area.

\section{BORE-HOLE WATER LEVELS AND SURFACE-ICE MOTION}

The water levels in the three bore holes which eventually connected in 1975 were continuously recorded using pressure transducers accurate to $\pm 0.35 \mathrm{~m}$ (Fig. 2). The water levels fluctuated as much as 40-6o m over periods of several days, with peaks usually occurring about $2 \mathrm{~d}$ after peaks in water input at the glacier surface. This agrees with the earlier results (Hodge, 1976). The long-term fluctuations in bore holes $75^{-8}$ and 75-14, however, were synchronous, implying that bore-hole water levels are probably representative over an area of the glacier bed at least $100 \mathrm{~m}$ in extent rather than the $10 \mathrm{~m}$ reported originally. This corresponds to about half the glacier thickness at this point. This figure of $100 \mathrm{~m}$ was suggested by daily soundings of two bore holes in 1973 but continuous recording in two new bore holes was necessary to consider it valid. Finally, the correlation between these two bore holes and the third one, $75^{-1}$, about $400 \mathrm{~m}$ up-glacier, is also fairly good, suggesting that the representative extent may be considerably larger than $100 \mathrm{~m}$.

The surface motion of the glacier was also measured at least once a day, weather permitting, at each of these three bore holes. Because of the small displacements involved, a 


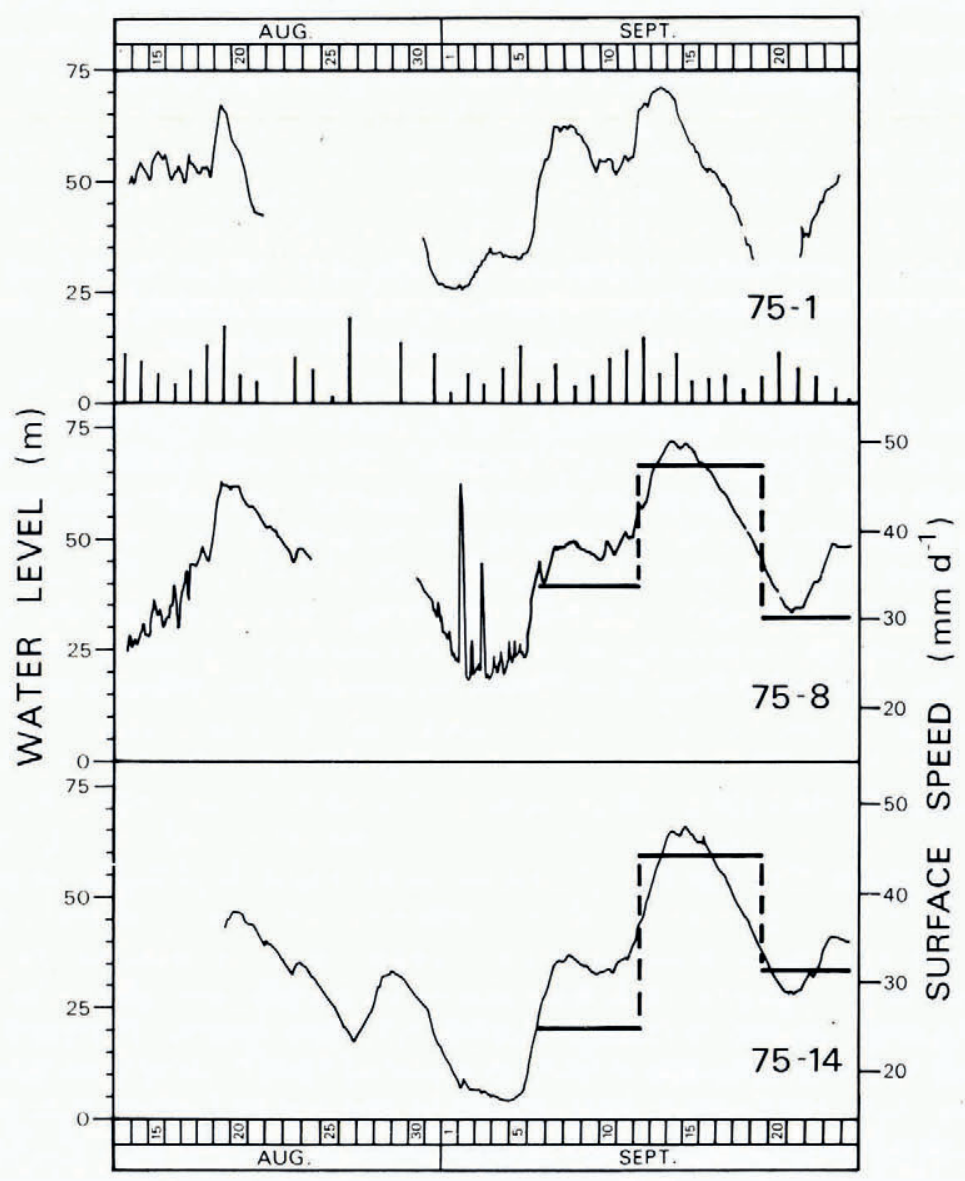

Fig. 2. Water levels in the three 1975 bore holes which connected with the basal water system. Holes 75-8 and 75-14 were about $100 \mathrm{~m}$ apart and hole $75^{-1}$ was about $400 \mathrm{~m}$ up-glacier from the other two. Relative values of daily liquid input are indicated by the vertical bars along the bottom of the upper graph. The origins of the water-level axes are not known exactly but are approximately the same height above the bed (about $90-110 \mathrm{~m})$. The relative accuracy of the water levels is about $\pm 0.35 \mathrm{~m}$. The surface speed at the lower two bore holes, accurate to about $\pm 2 \mathrm{~mm} \mathrm{~d}^{-1}$, is indicated by the heavy horizontal lines.

few centimeters a day, the surveying had to be precise. Measurements were made with a distance-measuring instrument and were normalized using a standard distance measured to the far side of the glacier. To reduce errors still further, only surveys done before sunrise were retained, and only time intervals of $5 \mathrm{~d}$ or greater were used to compute the motion. The net result of these constraints, coupled with some bad weather and an instrument break-down, was that no reliable data survived for the up-glacier bore hole $75^{-1}$, and only three data points were obtained for each of the other two bore holes. These data are plotted in Figure 2; they are accurate to about $\pm 2 \mathrm{~mm} \mathrm{~d}^{-1}$. The peak speed corresponds well with the major peak in water level. Assuming that the bore-hole water levels are an indication of the basal water pressures and that short-term velocity variations are due to variations in sliding rather than internal deformation, this lends strong support to a commonly held hypothesis that the sliding of a temperate glacier is strongly influenced by the basal water pressure (for example, Paterson, I969; Raymond, r97 ; Hodge, r974). 


\section{Comparison with Blue Glacier results}

Recent work on Blue Glacier, Washington, using bore-hole photography, has yielded important information on basal sliding and on the character of the ice-rock interface at the glacier bed (Engelhardt and others, 1978). It is useful to compare and interpret the drilling results in the light of their findings.

Engelhardt and others (1978) found a layer of gravel-like material about $10 \mathrm{~cm}$ thick between the bedrock and glacier sole, which is actively involved in the sliding process. The voids in this "active sub-sole drift", as they term it, are only partly filled with interstitial ice, the remainder being saturated with water at a pressure near the ice overburden pressure. Thus, it is directly different from the layer of debris-laden ice usually present immediately above the glacier sole. They also concluded this layer is extremely impermeable, probably due to the existence of a series of interconnecting "permeability barriers", for example, areas" devoid of sub-sole drift, ${ }^{*}$ where the glacier sole is in direct contact with bedrock. These barriers enclose areas of sub-sole drift and maintain the high interstitial water pressure. Penetration of the drift by a bore hole containing a high enough column of water would pressurize it and thus might eventually allow the permeability barriers to be breached. A sufficient supply of water would also be necessary to form and maintain the connection.

This picture is entirely consistent with the one generated by the South Cascade bore holes and discussed earlier. A drill which reaches the glacier bed but does not immediately connect with an active water system has simply arrived at a layer of sub-sole drift (or at one of the permeability barriers). The fact that a connection is rarely, if ever, produced by continuing to supply drill power after reaching the bed supports the concept of permeability barriers. Weeks or months of pressurization by the bore-hole water column are usually necessary before sufficient ice-bed separation takes place to breach the seals leading to the active part of the basal water system.

The action of the hot-water drill at the glacier bed also suggests the presence of this sub-sole drift. The drill, which would always descend through the i 5-30 $\mathrm{m}$ of debris-laden basal ice known to exist in the area of the drilling (Hodge, 1976) without any detectable drop in drillrate (about $60 \mathrm{~m} \mathrm{~h}^{-1}$ ), would always stop abruptly when it reached the bed, often shutting off the flow of drill water so quickly that the pump at the surface would stall. For the next hour or so, hot water was then pumped against the interface to attempt to force a connection with the active basal water system. During this time, the drill would usually descend slowly another $5^{-1} 5 \mathrm{~cm}$. Since the drill probe was $3.6 \mathrm{~m}$ long, it is unlikely this was due to leaning over of the probe inside the melted cavity. Instead, it seems that the drill was slowly working its way down into the sub-sole drift. The thickness of the layer implied by this interpretation agrees well with that found on Blue Glacier.

If the hydraulically inactive areas found by the drilling on South Cascade Glacier are taken to be areas of sub-sole drift, then the area percentages arrived at earlier imply that sub-sole drift covers well over half of the bed of the glacier, ranging from $60-70 \%$ in $1973-74$ to $90 \%$ in $1975-77$. This assumes that all bore holes penetrated the debris-laden basal ice sufficiently far to reach the "true" bed. This is a definite problem with the electrothermal drilling, but as discussed later, there is reason to believe that most of the bore holes did, in fact, reach the bed. Moreover, this criticism probably does not apply to the hot-water drill, since it does not appear to be slowed by debris-laden ice and the small advance usually made by this drill after reaching the bottom seems to indicate that sub-sole drift was indeed penetrated. If only the hot-water drilling results are considered, the sub-sole drift would cover a full $90 \%$ of the bed, thus reinforcing this conclusion.

* The word "active" used by Engelhardt and others (1978) in "active sub-sole drift" refers to the fact that the material is actively involved in the sliding process. The word will be omitted to avoid confusion with the hydraulically "active" water system referred to in this paper. 
Engelhardt and others (1978) suggested that bore-hole connection by bed pressurization may be effective over distances as great as $50 \mathrm{~m}$. If the active conduits are assumed to be parallel and to cover about $10 \%$ of the bed area, then for areas of the bed to exist beyond the reach of bed pressurization, the conduits would have to be over $100 \mathrm{~m}$ apart and greater than Io $\mathrm{m}$ in width. Since the latter is unlikely, it is probable that no such areas exist and that any bore hole will eventually connect with the active basal water system.

A second conclusion reached by Engelhardt and others (1978) was that the active subglacial conduits were essentially at atmospheric pressure. This is certainly implied by their observations but it does not agree with the South Cascade Glacier results. In the eight bore holes which connected in 1973 and 1974 , the water levels during the summer averaged $66.5 \%$ of the ice thickness, with a temporal and spatial variance of about $\pm 8.5 \%$ (Hodge, I976). The absolute values of the water levels in the 1975 bore holes (Fig. 2) are, unfortunately, not known exactly, but based on the maximum length of transducer cable available (100 m), they must have been approximately in the same range. The water level in the one bore hole which connected in 1977 was significantly deeper, averaging about $50 \%$ of the ice thickness and occasionally dropping to a minimum of about $40 \%$, * but, as mentioned earlier, this was probably due to a temporary period of abnormal weather. Thus, the water pressure in the active subglacial conduits under South Cascade Glacier during the summer is over one-half, and possibly as high as three-quarters, of the ice overburden pressure.

A third conclusion reached by Engelhardt and others (1978) was that synchronism in the water-level fluctuations in their bore holes was controlled by constrictions in the basal "leakage passageways" from the bore holes to the subglacial conduits. This does seem reasonable in their case, since the synchronism occurred in holes which connected simultaneously, thus implying that they had, at least in part, a common leakage passageway to the same subglacial conduit. The hole separations were approximately 30 and $65 \mathrm{~m}$, so this explanation may well apply to the South Cascade Glacier bore holes $73-6$ and $73-7$, which were only ro m apart, but it becomes progressively more difficult to apply as the bore holes become further separated. The good synchronism shown by the water levels in the 1975 bore holes (Fig. 2), I oo and $400 \mathrm{~m}$ apart, is an example; it is extremely difficult to imagine a common leakage passageway forming between holes separated by almost twice the ice thickness and almost half the glacier width, particularly when none of the holes connected at the same time. In this case, it seems more likely that different connections were formed to the same active subglacial conduit system and that synchronism in the fluctuations is a consequence not of the nature of the actual connection but of real widespread changes in basal water pressure. The correlation with changes in glacier surface motion also supports this viewpoint.

On the other hand, a connection formed by bed pressurization may be more likely to be controlled by leakage passageway constrictions, especially when the water flux through the passageway is changing rapidly and especially during the initial stages following formation. This could explain why wild fluctuations occurred between $3_{1}$ August and 5 September in bore hole $75^{-8}$, which connected by bed pressurization, but did not occur in bore hole 75-14, which did not connect by bed pressurization. In fact, the short-period fluctuations continued to be more pronounced in bore hole $75-8$ for another week or so, but with a greatly diminished amplitude. After about 12 September, the curves look very similar. This suggests that the continued flux of water through the leakage passageway in bore hole $75-8$ eventually widened the constrictions to the point where they could no longer influence the water-level fluctuations significantly.

The probable explanation for the differences in bore-hole water levels between Blue Glacier and South Cascade Glacier lies in the relative locations of the two sets of bore holes. The Blue

\footnotetext{
* Continuous recording of the water level in this bore hole was done but, due to various problems with the transducer, recorder, and batteries, very little usable record was obtained.
} 
Glacier holes were relatively near the glacier margin, whereas the South Cascade Glacier holes were usually drilled along the general area of the thalweg. Thus the Blue Glacier bore holes may be more likely to connect with conduits at atmospheric pressure. This is substantiated by two recent bore holes drilled in Blue Glacier in 1977 (oral communication from W. B. Kamb, 1978). These were drilled near the middle of the glacier and, after connection, the water levels averaged about $55 \%$ of the ice thickness, a figure much more consistent with water levels on South Cascade Glacier, particularly in bore hole 77-I (both glaciers were subject to the same period of very high melt in 1977).

Finally, Engelhardt and others (1978) have given strong evidence to show that cable-tool drilling and/or bore-hole photography are necessary to verify that the true glacier bed has been reached. Since such techniques were not used on South Cascade Glacier, it may be that some or all of the bore holes never really reached the bed and that the resulting water-level measurements are not valid representations of conditions in the basal water system. There are however, several indications that the true bed was indeed probably reached. First, as pointed out earlier, the hot-water drill was completely unaffected by debris-laden ice and there is even some suggestion that it penetrated the sub-sole drift. This type of drilling may be as effective as cable-tool drilling. There was also no evidence to suggest the hot-water drill penetrated significantly deeper than the earlier electrothermal drilling at the same sites, supporting the belief that the very persistent electrothermal drilling had indeed reached the bed. Bore-hole depths were also very consistent with the radio echo-sounding depths. Secondly, at least six of the 12 connections on South Cascade Glacier were made while drilling at the bed, almost always within seconds, or at most minutes, of the drop in drill-rate which indicated the "bed" had been reached. In these cases, there simply was insufficient time to create a significantly long leakage passageway by bed pressurization. Thus the drill must have penetrated the active subglacial conduit system directly. Thirdly, in the case of these connections established while drilling at the bed, the drop in water level usually took place very rapidly, again within seconds or, at most, a few minutes. This again suggests that direct penetration of the active basal water system took place, since it is difficult to see how else Ioo-200 l of water could have been absorbed so rapidly. Fourthly, the very good synchronism of the water-level fluctuations over large distances suggests connection with the true basal water system. Finally, it may not be necessary to reach the true bed anyway, if all that is desired is a hydraulic connection. Active conduits may extend some distance above the interface and, as pointed out by Glen ( I954), bore holes filled with water at least $150-200 \mathrm{~m}$ deep will tend to enlarge themselves and penetrate deeper into the ice.

\section{Summary}

The decrease in the chance of a bore-hole connecting with the active subglacial water system during 1975 , and again in 1977 using a hot-water drill, has resulted in some interesting deductions about the subglacial water system of South Cascade Glacier. Most of the bed, possibly as much as $90 \%$, is hydraulically inactive and isolated from a few active subglacial conduits. These sealed-off areas probably consist of the sub-sole drift and permeability barriers found recently at the bed of Blue Glacier by Engelhardt and others (1978). An increase in the area of bed covered by these features probably caused the decrease in the chance of bore-hole connection. This was apparently the result of an internal change in the subglacial hydraulic system. Such a change may be an example of the vulnerability of Röthlisberger channels to closure as pointed out by Nye (1973) and is not unreasonable in the light of glacio-hydrological phenomena such as jökulhlaups, seasonal storage and release of water, or variations in basal sliding.

Possibly the interstitial water in the sub-sole drift corresponds to the "sheets" of water considered by Weertman (1972) to cover most of the bed of a glacier. Like the water in 
Weertman's sheets, the water in the sub-sole drift may be produced by melting from the glacier sole by geothermal heat and the heat produced by internal deformation and basal sliding. The flow of interstitial water in the sub-sole drift must be extremely low in view of the apparent very low permeability of the layer, but it may be sufficient to carry away the relatively small amount of water produced by bottom melting. The permeability barriers implied by both the South Cascade Glacier and the Blue Glacier results may correspond to the pressure barriers shown by Weertman to exist adjacent to an active conduit when the water pressure in the conduit is less than the ice overburden pressure. Such barriers prevent the flow of sheet water into a conduit and may explain why the interstitial water in the sub-sole drift is "hydraulically isolated" from the active conduits. Bottom melt water may thus flow very slowly as a form of sheet flow through the sub-sole drift but remain more or less isolated from the surface melt water and rainfall being transported rapidly along the glacier bed in a few active channels.

A bore hole which reaches a hydraulically isolated area should eventually connect by bed pressurization, provided there is a sufficient supply of water. Such "indirect" connections, formed after drilling, must be distinguished from "direct" connections, formed while drilling. They should still be useful for basal water-pressure measurements but they are not as valuable as direct connections, since they do not give information on the location of the active basal water system and they may be affected in an unknown way by the nature of the leakage passageway. Direct connections give confidence in the belief that the true basal water system has been reached, whereas indirect connections, particularly if they occur over large distances such as $50 \mathrm{~m}$ or so, could result in a somewhat misleading picture of the true situation.

If most of the area of a glacier bed is hydraulically isolated sub-sole drift, this has important consequences for glacier sliding theories. Changes in the amount of water having access to the glacier bed will take considerable time to affect the interstitial water pressure in the more widespread sub-sole drift, since the permeability barriers will have to be breached by much the same bed pressurization (or "depressurization") process taking place with the bore holes. It may be that such features control large-scale glacier sliding changes, such as seasonal velocity variations, rather than the mechanism of conduit closure by ice deformation versus conduit enlargement by frictional melting suggested, for example, by Hodge (1974) and Tangborn and others ([1975]), and modelled by Röthlisberger (1972). The existence of sub-sole drift and permeability barriers, or something similar, over large areas of a glacier bed needs to be confirmed and the interaction of the interstitial water with the active subglacial water system investigated.

\section{Acknowledgements}

The writer thanks the U.S. Forest Service, Mount Baker-Snoqualmie National Forest, for permission to drill these bore holes, Mr P. Taylor for designing and building much of the drilling equipment, and Ms Diane Evans for doing most of the radio echo-sounding work. He also thanks Drs C. F. Raymond, W. D. Harrison, and M. F. Meier for their helpful comments and suggestions, many of which are incorporated into the final manuscript.

\section{REFERENCES}

Engelhardt, H. F., and others. 1978. Basal sliding and conditions at the glacier bed as revealed by bore-hole photography, by H. F. Engelhardt, W. D. Harrison, and [W.] B. Kamb. Fournal of Glaciology, Vol. 20, No. 84, p. 469-508.

p. $469-508$.
Glen, J. W. 1954 . The stability of ice-dammed lakes and other water-filled holes in glaciers. Fournal of Glaciology,

Vol. 2, No. 15, p. 316-18.
Hodge, S. M. 1974. Variations in the sliding of a temperate glacier. Journal of Glaciology, Vol. 13, No. 69, p. $349-69$. 
Hodge, S. M. 1976. Direct measurement of basal water pressures: a pilot study. Fournal of Glaciology, Vol. 16, No. 74 , p. $205^{-18}$.

Nye, J. F. 1973. Water at the bed of a glacier. Union Géodésique et Géophysique Internationale. Association Internationale d'Hydrologie Scientifique. Commission de Neiges et Glaces. Symposium on the Hydrology of Glaciers, Cambridge, 7-I3 September 1969 , p. 189-94. (Publication No. 95 de l'Association Internationale d'Hydrologie Scientifique.)

Paterson, W. S. B. I 969 . The physics of glaciers. Oxford, etc., Pergamon Press. (The Commonwealth and International Library. Geophysics Division.)

Raymond, C. F. 197 I. Flow in a transverse section of Athabasca Glacier, Alberta, Canada. Fournal of Glaciology, Vol. 10, No. 58, p. $55^{-84}$.

Röthlisberger, H. 1972. Water pressure in intra- and subglacial channels. Fournal of Glaciology, Vol. I I, No. 62, p. $177^{-203}$.

Shreve, R. L. 1972. Movement of water in glaciers. Journal of Glaciology, Vol. I 1, No. 62, p. $205^{-1} 4$.

Tangborn, W. V., and others. [1975.] A comparison of glacier mass balance by glaciological, hydrological, and mapping methods, South Cascade Glacier, Washington, [by] W. V. Tangborn, R. M. Krimmel, and M. F. Meier. [Union Géodésique et Géophysique Internationale. Association Internationale des Sciences Hydrologiques. Commission des Neiges et Glaces.] Symposium. Neiges et glaces. Actes du colloque de Moscow, août 197I, p. 185-96. (IAHSAISH Publication No. I04.)

Watts, R. D., and others. 1975. Radio-echo sounding on South Cascade Glacier, Washington, using a longwavelength, mono-pulse source, by R. D. Watts, A. W. England, R. S. Vickers, and M. F. Meier. Fournal of Glaciology, Vol. 15, No. 73, p. 459-61. [Abstract.]

Weertman, J. 1972. General theory of water flow at the base of a glacier or ice sheet. Reviews of Geophysics and Space Physics, Vol. 10, No. 1, p. 287-333.

\section{DISCUSSION}

R. A. Bindschadler: Only a comment on the nature of the pressure recording in one of the I 975 indirect connections; the signal contained much more high-frequency variation when the water pressure was low. I suggest this could be an indication of the glacier attempting to seal off the channel-hole connection in this type of hole.

S. M. Hodge: That is a good point. Constrictions would be more likely to form when water pressures are low.

L. A. Lliboutry : Similar results have been found by F. Gillet on Glacier de Saint-Sorlin. I am very happy to see that points I have maintained for at least ro years are now confirmed by extensive field evidence: (I) There is in most cases interconnection. (What I call interconnection is generally Hodge's indirect connection.) It may be through moraine, through glacial striae, or through rock joints. (2) The effective pressure (ice pressure less the pressure of interconnected water) may often be considered, as a first rough approximation, to be proportional to the ice pressure. Now you have always found it was in the range $50-70 \%$.

J. Weertman: The large number of holes that did not immediately connect to the water system could be evidence for a water film. If the water film is thin (less than I mm thick), it would take a long time for water to flow from the hole or to the hole, into or out of the film.

Hodge: This is true. I have tried here, however, to show how the drilling results are compatible with the direct experimental observations of Kamb and others. I did suggest that possibly the interstitial water in the sub-sole drift could be identified with a Weertman type of sheet flow. 